\title{
Acute Toxicity of $\mathrm{NH}_{4} \mathrm{Cl}$ to Tambra Fish
}

\author{
(Tor Tambroides) Fry
}

\author{
Gunawan Pratama Yoga ${ }^{a, *}$, Kristin Noni Riyanti Buraen ${ }^{b}$, and Sutanto ${ }^{b}$

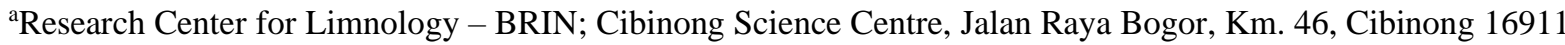 \\ *E-mail: yoga@limnologi.lipi.go.id

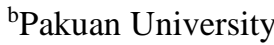

Received 21 November 2021

Accepted 21 December 2021

Published 30 December 2021

DOI: $10.51264 /$ inajl.v2i2.21

\begin{abstract}
Ammonia is one of the nutrient wastes products which can be toxic to all vertebrates, including fish. Usually, ammonia toxicity is expressed as Total Ammonia Nitrogen (TAN, mgN/L). Tambra fish (Tor tambroides) is freshwater fish with important economic value in some areas in Indonesia. According to overfishing and forest degradation, the fish has become threatened. This research aimed to calculate the $\mathrm{LC}_{50}$ value of ammonia to Tambra fish (Tor tambroides) and estimate NOEC, LOEC, and MATC values of ammonia to Tambra fish (Tor tambroides). This study was conducted using the static test method with two steps. The first stage is a preliminary test, where the preliminary test is observed for 24 hours With five concentrations excluding control. Whereas in the second stage that is carried out, observation for 96 hours with four concentrations excluding control. The Probit test is Performed to obtain $\mathrm{LC}_{50}$ value results, then proceed with ammonia analysis using the Salicylate Test Kit method. The results showed that ammonia had acute toxicity with $\mathrm{LC}_{50}-96$ hour value of $\mathrm{NH}_{4} \mathrm{Cl}$ against Tambra fish fry (Tor tambroides) in the amount of $354.615 \mathrm{mg} / \mathrm{L}$. Ammonia caused acute toxicity to Tambra fish fry (Tor tambroides). The $\mathrm{LC}_{50}-96$ hour value was $354.615 \mathrm{mg} / \mathrm{L}$ in the form of Total Ammonia Nitrogen (TAN) or it was equivalent to un-ionized Ammonia $\left(\mathrm{NH}_{3}\right)$ of $9.8937 \mathrm{mg} / \mathrm{L}$, while values of the Lowest Observed Effect Concentration (LOEC) and No Observed Effect Concentration (NOEC) of ammonia on Tambra fish (Tor tambroides) were $578.24 \mathrm{mg} / \mathrm{L}$ and $280.18 \mathrm{mg} / \mathrm{L}$, respectively.
\end{abstract}

Keywords: Ammonia, $\mathrm{LC}_{50}-96$-hour, Tambra fish, toxicity

\section{INTRODUCTION}

Ammonia in the aquatic environment primarily comes from plants and animals excretion, a decomposition product of organisms and sewage, agricultural run-off, industrial wastes, and volcanic activity. Increasing ammonia concentration in freshwater can be toxic for aquatic organisms. Ammonia toxicity usually is expressed as total ammonia (TAN) in the aquatic environment (Randall \& Tsui, 2002). The total ammonium is the total sum of ammonium $\left(\mathrm{NH}_{4}^{+}\right)$and ammonia $\left(\mathrm{NH}_{3}\right)$. The latter is considered a product of body protein and nucleic acid biochemical degradation (Mardonesa et al. 2019). Increasing ammonia concentration in freshwater is harmful to aquatic organisms, such as fish. The toxic effect of ammonia on fish includes an imbalance of ionic regulation in blood plasma (Eddy, 2005), increased ventilation rates and gill epithelium damage, reduction of blood-carrying capacity (Russo, 1985), depletion of adenosine triphosphate 
(ATP) in the brain depletion of adenosine triphosphate (ATP) in the brain (Camargo \& Alonso, 2006), and the disruption of osmoregulatory and circulatory activity disrupting normal metabolic functioning of the liver and kidneys and the interruption of osmoregulatory and circulatory activity disrupting normal metabolic functioning of the liver and kidneys (Arillo et al., 1981; Tomasso et al., 1980).

Tambra (Tor tambroides), one of the mahseer fishes (Tor spp), is well-known as a large-bodied fish of Cyprinidae family. There are 20 species of this genus identified in the world. 4 live in Indonesian freshwater (Haryono \& Tjakrawidjaja, 2006). Individual fish can reach over $50 \mathrm{~kg}$, which has become popular as premier sport fishing (Pinder et al., 2019). Despite the high nutritional value and their ability to provide food security, Tambra also has high religious and cultural significance in several regions in Indonesia. For example, for Batak people in North Sumatra, the fish is used as a substitute for Batak fish (Neolissochilus thieenmanni) in many cultural ceremonies.

The fish have suffered population declines due to anthropogenic activities, such as pollution, habitat loss caused by deforestation and agricultural development, hydropower dan construction, and over-fishing. This species is also listed as endangered species by the International Union for Conservation of Nature (IUCN) (Pinder et al. 2019). Therefore, the conservation and protection of this species from harmful compounds such as ammonia is vital. To support the effort of Tambra fish conservation through its domestication, this research aimed to calculate the $\mathrm{LC}_{50}$ value of ammonia to Tambra fish (Tor tambroides) and estimate NOEC, LOEC, and MATC values of ammonia to Tambra fish (Tor tambroides). The novelty of this study is providing information of ammonia toxicity to the Tambra fish (Tor tambroides). Finally, we expect this study can contribute significantly to aquatic toxicity research.

\section{METHODS}

\section{Time and Location}

This research was conducted at the Aquatic Laboratory facility of Research Center for Limnology, Indonesian Institute of Sciences (LIPI) from July - September 2019.

\section{Fish Handling}

Tambra fish (Tor tambroides) fry, used for toxicity test was provided from Freshwater Research Unit, Ministry of Marine Affairs and Fisheries Republic of Indonesia. Eight hundred fish fry aged approximately one month with an average weight of 0.72 grams were acclimatized for two weeks before the test was conducted. During acclimatization and experiment, the fry was fed with a commercial fish diet. Fish were fed in the morning, and water quality and mortality were recorded during the acclimatization period in the afternoon. During the acclimatization period, the fish were put into a reservoir filled with water and aerated. The fish were acclimatized for seven days and fed. The purpose of this acclimatization is to adapt the fish to the experimental condition. A day before the toxicity test was conducted, fish stopped feeding.

\section{Chemicals}

To test for toxicity, we used anhydrous Ammonium Chloride $\left(\mathrm{NH}_{4} \mathrm{Cl}\right.$, HIMEDIA) to make working ammonia concentrations during the toxicity test. Ammonium Chloride was diluted by distilled water for making an Ammonium stock solution (10.000 ppm). Agriculture lime $\left(\mathrm{CaCO}_{3}\right)$ was used for controlling water $\mathrm{pH}$ around seven during the toxicity test.

\section{Toxicity Test}

An acute toxicity test to determine the lethal concentration $\left(\mathrm{LC}_{50}\right)$ of ammonia to Tambra fish was conducted according to USEPA (2002) 
with some modifications. The assay consisted of two steps, a range finding, and a definitive test. A series of ammonia concentrations were used in the range-finding test to determine Tambra fish's short-term lethal ammonia toxicity. 18 glass aquariums, volume 30 liter, filled with aged, aerated tap water as the diluent of ammonia. The test was ended in 48 hours, and the dead fish were recorded at the end of the test. Ammonia concentration during the toxicity test was measured as Total Ammonia Nitrogen (TAN). Total Ammonia Nitrogen (TAN) series in range-finding test were $0 \mathrm{mg} / \mathrm{L}$, $25 \mathrm{mg} / \mathrm{L}, 5 \mathrm{mg} / \mathrm{L}, 50 \mathrm{mg} / \mathrm{L}, 100 \mathrm{mg} / \mathrm{L}, 400$ $\mathrm{mg} / \mathrm{L}$ and $800 \mathrm{mg} / \mathrm{L}$, with 3 replications. Fish mortality records from the range-finding test were used to determine tentative $\mathrm{LC}_{50}$. Tentative $\mathrm{LC}_{50}$ result from the range-finding test then was used to determine ammonia concentrations in the Acute definitive test.

Eight fish fry were used in each aquarium on the range-finding test, and fish mortality was recorded every 24 hours for 48 hours. Dead fish was removed immediately during observation. Fish mortality data from the range-finding test was calculated to determine the ammonia concentration sequence used in the definitive test.

Based on range-finding test result, TAN concentration sequence in definitive test were set up, $5 \mathrm{mg} / \mathrm{L}, 16 \mathrm{mg} / \mathrm{L}, 27 \mathrm{mg} / \mathrm{L}, 38 \mathrm{mg} / \mathrm{L}$ dan $50 \mathrm{mg} / \mathrm{L}, 3$ replicates. Twenty fish in each aquarium were exposed in the toxicity test. Fish dead were recorded and removed every 24 hours. The definitive test was conducted for 96 hours (4 days). At the end of the test, fish mortality data were then used to calculate $\mathrm{LC}_{50^{-}}$ 96h. An acute toxicity test was conducted on static conditions without water renewal. Fish was not fed during the test. The test was valid when fish mortality in control was less than $10 \%$ of exposed fish.

\section{Water Quality Parameters}

Physico-chemical parameters measured during the toxicity test were temperature, $\mathrm{pH}$, and Dissolved Oxygen (DO). Measurement was conducted using a portable water quality checker (WQC) HORIBA ${ }^{\circledR}$ U50. Physicochemical parameters were measured every day at 10:00 am.

\section{Analysis}

Probit analysis was used to calculate $\mathrm{LC}_{50^{-}}$ 96h from fish mortality data. Probit analysis was established using software Simply Probit version 1.2 (PISCES Conservation Ltd, 2005).

No observed adverse effect concentration (NOAEC) and the lowest adverse effect concentration (LOAEC) were determined through one-way ANOVA followed by Tukey analysis in excel statistical package. The geometric mean of the NOAEC and the LOAEC was then calculated to provide Maximum Acceptable Toxicant Concentration (MATC). MATC is a value calculated through acute toxicity tests to help set water quality regulations to protect aquatic life (Rand \& Gary, 1995).

\section{RESULTS AND DISCUSSION}

\section{Acclimatization}

Acclimatization aims to condition the Tambra fish (Tor tambroides) in the prepared aquarium so that the Tambra (Tor tambroides) fry can adapt to the new environment. Acclimatization lasted for seven days. During the acclimatization period, $\mathrm{pH}$ value and temperature were ranged between $6.8-7.5$ and $26-27^{\circ} \mathrm{C}$, respectively.

Based on Lesmana \& Dermawan (2001), the optimum $\mathrm{pH}$ and temperature for Tambra fish fry were $7-7.5$ and at a temperature of $25-27^{\circ} \mathrm{C}$, respectively. Thus, acclimatization took place at the optimal $\mathrm{pH}$ and temperature for the growth of Tambra fish fry.

During the acclimatization, fish were fed by a commercial fish diet in the morning and the afternoon. Water quality and mortality were recorded during the acclimatization period. The mortality rate during the acclimatization period was $4 \%$. This rate was below $10 \%$, which was allowed during this period (APHA, 2000). A 
day before the toxicity test was conducted, fish stopped from feeding (USEPA, 2002).

\section{Range Finding Test}

Tambra fish fry range-finding test showed that mortality was observed on $100 \mathrm{mg} / \mathrm{L}, 400$ $\mathrm{mg} / \mathrm{L}, \quad$ and $\quad 800 \mathrm{mg} / \mathrm{L}$ of ammonia concentrations.

The relationship between $\mathrm{NH}_{4} \mathrm{Cl}$ concentration and the number of Tambra fish deaths in this preliminary test for 48 hours can be seen Figure 1.

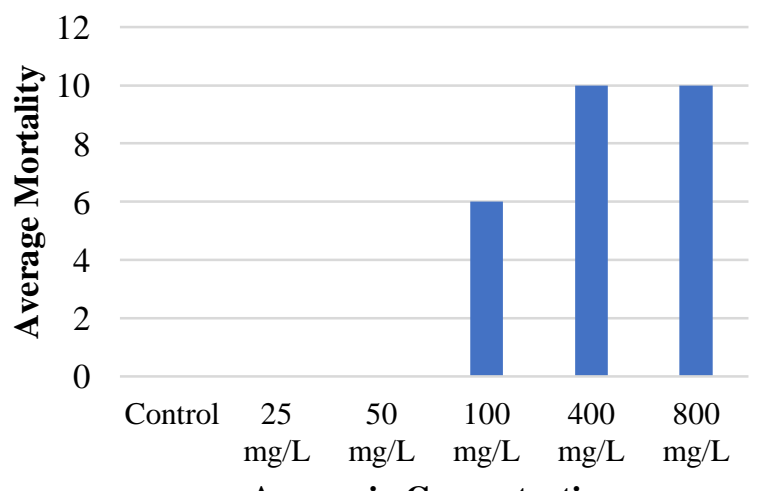

Ammonia Concentration

Figure 1. Range Finding Test Results

Based on Figure 1, it can be seen that the average fish mortality at concentrations of 0 , 25 , and $50 \mathrm{mg} / \mathrm{L}$ was zero, while at $100 \mathrm{mg} / \mathrm{L}$, mortality was six fish. And the highest mortality occurred at concentrations of 400 and $800 \mathrm{mg} / \mathrm{L}$, where all test animals were dead. However, in control, all of the test animals were alive. Based on the range-finding result, ammonia concentrations in the definitive test were determined. The concentrations were $67.81 \mathrm{mg} / \mathrm{L}, 107.69 \mathrm{mg} / \mathrm{L}, 280.18 \mathrm{mg} / \mathrm{L}$ and $578.34 \mathrm{mg} / \mathrm{L}$, respectively.

\section{Definitive Test}

In the definitive test, observations were made for 96 hours to see fish mortality, and temperature and $\mathrm{pH}$ were measured. So that the
$\mathrm{LC}_{50}$ value can be calculated, the graph of the relationship between $\mathrm{NH}_{4} \mathrm{Cl}$ concentration and mortality of Tambra fish can be seen in Figure 2

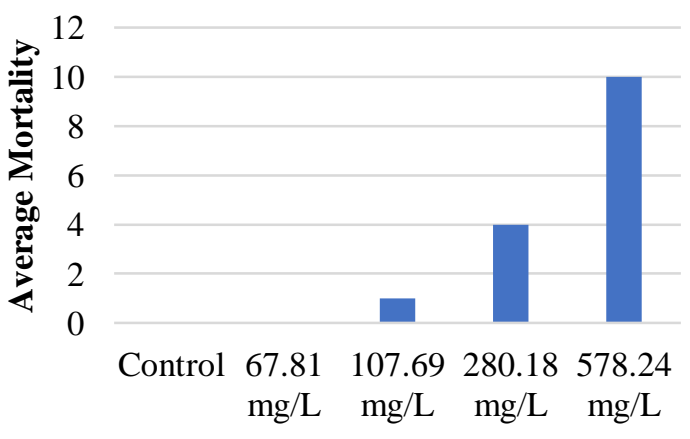

Ammonia concentration

Figure 2. Definitive Test Result

Based on Figure 2, it can be seen that the average mortality of the test animals at the control and $67.81 \mathrm{mg} / \mathrm{L}$ were zero. At a concentration of $107.69 \mathrm{mg} / \mathrm{L}$, there was the death of 1 test animal. At a concentration of $280.18 \mathrm{mg} / \mathrm{L}, 4$ test animals died, and at a concentration of $578.24 \mathrm{mg} / \mathrm{L}$, all test animals died. $\mathrm{LC}_{50}$ 96h from Probit analysis result for Tambra fish fry was $354.615 \mathrm{mg} / \mathrm{L}$ TAN. with lower confidence, and upper confidence limit was $228.650 \mathrm{mg} / \mathrm{L}$ and $549.975 \mathrm{mg} / \mathrm{L}$, respectively. Un-ionized ammonia $\left(\mathrm{NH}_{3}-\mathrm{N}\right)$ is considered as the most toxic fraction of TAN (USEPA, 1998). According to temperature and $\mathrm{pH}$ measurement during the acute definitive test, the TAN value was equal to $9.89 \mathrm{mg} / \mathrm{L}$ $\mathrm{NH}_{3}-\mathrm{N}$ with a lower and upper confidence limit was $6.38 \mathrm{mg} / \mathrm{L} \mathrm{NH}_{3}-\mathrm{N}$ and $15.34 \mathrm{mg} / \mathrm{L} \mathrm{NH}_{3}-\mathrm{N}$, respectively.

According to Rumampuk et al. (2010) and Yulaipi \& Aunorohim (2013), the longer the exposure time of a toxicant to test animals followed by increasing concentrations during exposure will cause mortality on test animals. This is because the mortality of the test organisms during toxicity test is due to the damage of their respiratory organ (Robert, 1978).

Compared to some freshwater fish such as Catla catla, Labeo bata, Cyprinus carpio, 
Oreochromis mossambica, Rasbora maninjau and Gobiopterus brachypterus, Tambra fish fry is more tolerant to TAN, because its $\mathrm{LC}_{50}-96 \mathrm{~h}$ is higher than the $\mathrm{LC}_{50}-96 \mathrm{~h}$ of those fish. Comparison of $\mathrm{LC}_{50}-96 \mathrm{~h}$ from several freshwater fish is presented in Table 1.

Table 1. $\mathrm{LC}_{50}$ of Ammonia to several freshwater fish

\begin{tabular}{|c|c|c|c|}
\hline No & Fish & $\begin{array}{c}\mathrm{LC}_{50} \\
\text { ammonia }\end{array}$ & Source \\
\hline 1 & Catla catla & $\begin{array}{ll}15 & \mathrm{mg} / \mathrm{L} \\
\text { TAN } & \end{array}$ & $\begin{array}{l}\text { Bhakta } \\
(2006)\end{array}$ \\
\hline 2 & Labeo bata & $\begin{array}{ll}10 & \mathrm{mg} / \mathrm{L} \\
\text { TAN } & \end{array}$ & $\begin{array}{l}\text { Bhakta } \\
(2006)\end{array}$ \\
\hline 3 & $\begin{array}{l}\text { Cyprinus } \\
\text { carpio }\end{array}$ & $\begin{array}{l}25 \mathrm{mg} / \mathrm{L} \\
\text { TAN. }\end{array}$ & $\begin{array}{l}\text { Bhakta } \\
\text { (2006) }\end{array}$ \\
\hline 5 & $\begin{array}{l}\text { Oreochromis } \\
\text { mossambica }\end{array}$ & $\begin{array}{ll}30 & \mathrm{mg} / \mathrm{L} \\
\text { TAN } & \end{array}$ & $\begin{array}{l}\text { Bhakta } \\
(2006)\end{array}$ \\
\hline 6 & $\begin{array}{l}\text { Elver } \\
\text { (Anguilla } \\
\text { bicolor) }\end{array}$ & $\begin{array}{l}467,4 \mathrm{mg} / \mathrm{L} \\
\text { TAN }\end{array}$ & $\begin{array}{l}\text { (Yoga \& } \\
\text { Nursodiya } \\
\text { nti, 2018) }\end{array}$ \\
\hline 7 & $\begin{array}{l}\text { Rasbora } \\
\text { maninjau }\end{array}$ & $\begin{array}{l}29.9 \mathrm{mg} / \mathrm{L} \\
\text { TAN }\end{array}$ & $\begin{array}{l}\text { (Yoga \& } \\
\text { Samir, } \\
\text { 2020a) }\end{array}$ \\
\hline 8 & $\begin{array}{l}\text { Gobiopterus } \\
\text { brachypterus }\end{array}$ & $\begin{array}{l}11.62 \mathrm{mg} / \mathrm{L} \\
\text { TAN }\end{array}$ & $\begin{array}{l}\text { (Yoga \& } \\
\text { Samir, } \\
\text { 2020b) }\end{array}$ \\
\hline
\end{tabular}

In determining the toxicity, data from toxicology test results are used to determine the concentration limit without effect called NOAEC (No Observed Adverse Effect Concentration). NOAEC is the highest concentration of the test substance that does not cause significant harmful effects on the test animals compared to the control in the toxicity test. LOAEC (The Lowest Observed Adverse Effect Concentration) is the lowest concentration of the test materialwhich has a significant effect on the test animals compared to the control in the toxicity test (Rand, 2008). The NOAEC and LOAEC values of Tambra fish for TAN are $280.18 \mathrm{mg} / \mathrm{L}$ and 578.24 $\mathrm{mg} / \mathrm{L}$, respectively. According to those values, the MATC of ammonia for Tambra fish is $402.51 \mathrm{mg} / \mathrm{L}$

Water quality during the toxicity test was still in the range of water quality requirements for Tambra fish (Lesmana \& Dermawan, 2001). Water temperature, $\mathrm{pH}$, and dissolved oxygen in the toxicity test tank are described in Table 2.

Table 2. Water Quality measurement result during Toxicity Tests

\begin{tabular}{lcc}
\hline \multicolumn{1}{c}{ Parameter } & Unit & Value \\
\hline Temperature & ${ }^{\circ} \mathrm{C}$ & $26.4(25.3-27.5)$ \\
$\mathrm{pH}$ & - & $7.6(7.4-8.4)$ \\
$\begin{array}{l}\text { Dissolved } \\
\text { Oxygen }\end{array}$ & $\mathrm{mg} / \mathrm{L}$ & $4.96(4.30-5.82)$ \\
\hline
\end{tabular}

\section{CONCLUSION}

Ammonia caused acute toxicity to Tambra fish fry (Tor tambroides). The $\mathrm{LC}_{50}-96$ hour value was $354.615 \mathrm{mg} / \mathrm{L}$ in the form of Total Ammonia Nitrogen (TAN) or it was equivalent to un-ionized Ammonia $\left(\mathrm{NH}_{3}\right)$ of $9.8937 \mathrm{mg} / \mathrm{L}$, while values of the Lowest Observed Effect Concentration (LOEC) and No Observed Effect Concentration (NOEC) of ammonia on Tambra fish (Tor tambroides) were $578.24 \mathrm{mg} / \mathrm{L}$ and $280.18 \mathrm{mg} / \mathrm{L}$, respectively. According to those values, the MATC of ammonia for Tambra fish is $402.51 \mathrm{mg} / \mathrm{L}$.

\section{ACKNOWLEDGEMENTS}

This research was part of Batak fish Conservation project which was funded by Research Center for Limnology - LIPI on 2019 fiscal year. 


\section{REFERENCES}

APHA. 2000. Standard Methods for the Examination of Water and Wastewater (19 $9^{\text {th }}$ edition). American Public Health Association, Washington DC, p 1038.

Arillo A, Margiocco C, Melodia F, Mensi P, and Schenone G. 1981. Ammonia toxicity mechanism in fish: Studies on rainbow trout (Salmo gairdneri Richardson.) Ecotoxicol. Environ. Saf, 5(3), 16-328.

Bhakta JN. 2006. Ammonia Toxicity to Four Freshwater Fish Species: Catla catla, Labeo bata, Cyprinus carpio and Oreochromis mossambica. Electronic Journal of Biology, 2(3), 39-41.

Camargo J and Alonso A. 2006. Ecological and toxicological effects of inorganic nitrogen pollution in aquatic ecosystems: A global assessment. Environ. Internat., 32, 831849.

Eddy FB. 2005. Ammonia in estuaries and effects on fish. Journal of Fish Biology, 67, 1495-1513. doi:10.1111/j.1095-8649.2005.00930.x.

Haryono and Tjakrawidjaya AH. 2006. Morphological Study for Identification Improvement of Tambra Fish (Tor spp.: Cyprinidae) from Indonesia. Biodiversitas, $7(1), 59-62$.

Lesmana DS and Dermawan I. 2001. Budidaya Ikan Hias Air Tawar Populer. Penebar swadaya, Jakarta.

Mardonesa A, González M, Rivas-Mancilla C, Vega R, Augsburger A, Encina F, and De los Ríos P.2019. Determination of acute toxicity of ammonium in juvenile Patagonian blenny (Eleginops maclovinus). Braz. J. Biol., 79(4), 646-650.

Pinder AC, Britton JR, Harrison AJ, Nautiyal P, Bower SD, Cooke SJ, Lockett S, Everard M, Katwate U, Ranjeet K, Walton S, Danylchuk AJ, Dahanukar N, and Raghavan R. 2019. Mahseer (Tor spp.) fishes of the world: status, challenges, and opportunities for conservation. Rev Fish Biol Fisheries, 29, 417-452. https://doi.org/10.1007/s11160-019-09566$\mathrm{y}$
Rand and Gary, 1995. Fundamentals of Aquatic Toxicology. CRC Press, Boca Raton. pp 943. ISBN 1-56032-090-7

Rand GM. 2008. The Toxicology of Fishes; Fish Toxicity Studies. Editor: Guilio dan Hinton. CRC Press, Boca Raton.

Randall DJ and Tsui TKN. 2002. Ammonia Toxicity in Fish. Marine Pollution Bulletin, 45, 17-23. https://doi.org/10.1016/S0025$326 \mathrm{X}(02) 00227-8$

Roberts RJ. 1978. Fish Pathology. Bailliere Tindal, London, p 571.

Rumampuk ND, Tilaar S, and Wullur S. 2010. Median Lethal Concentration (LC50) Insektisida Diklorometan pada Nener Bandeng (Chanos chanos Forsskal). Jurnal Perikanan dan Kelautan, 6(2), 87-91.

Russo RC. 1985. Ammonia, nitrite, and nitrate. In: Fundamentals of aquatic toxicology and chemistry. Rand GM and Petrocelli SR (Eds.). Hemisphere Publishing Corp., Washington DC, pp 455-471.

Tomasso JR, Goudie CA, Simco BA, and Davis KB. 1980. Effects of environmental $\mathrm{pH}$ and calcium on ammonia toxicity in channel catfish. Trans. Am. Fish Soc., 109, 229234.

USEPA (U.S. Environmental Protection Agency). 1998. Guidelines for Ecological Risk Assessment. EPA/630/R-95/002F. Risk Assessment Forum, Washington DC, USA, p 114.

USEPA. 2002. Methods for measuring the acute toxicity of effluents and receiving waters to freshwater organisms. EPA 600/490/027f. Cincinnati, $\mathrm{OH}$.

Yoga GP and Samir O. 2020a. Ammonia toxicity to endemic fish (Rasbora maninjau) of Lake Maninjau as a reference for water quality guidelines. IOP Conference Series: Earth and Environmental Science, 525, 1-7. DOI: $10.1088 / 1755-1315 / 535 / 1 / 012009$

Yoga GP and Samir O. 2020b. Ammonia Toxicity to Rinuak (Gobiopterus brachypterus) of Lake Maninjau. Indonesian Journal of Limnology, 1(1), 1218. 
Yoga GP and Nursodiyanti S. 2018. Ammonia Toxicity to Eels Fry. Prosiding Seminar Ikan 2018 (In Indonesian).

Yulaipi S and Aunurohim. 2013. Bioakumulasi Logam Berat Timbal $(\mathrm{Pb})$ dan
Hubungannya dengan Laju Pertumbuhan Ikan Mujair (Oreochromis mossambicus). Jurnal Sains dan Seni Pomits, 2(2), 23373520 . 